\title{
New Bruce-ladder multiplex PCR assay for the biovar typing of Brucella suis and the discrimination of Brucella suis and Brucella canis
}

\author{
Ignacio López-Goñi ${ }^{\mathrm{a}, *}$, David García-Yoldi a , Clara M. Marín ${ }^{\mathrm{b}}$, María J. de Miguel ${ }^{\mathrm{b}}$, \\ Elías Barquero-Calvo ${ }^{c}$, Caterina Guzmán-Verri ${ }^{\mathrm{c}}$, David Albert ${ }^{\mathrm{d}}$, Bruno Garin-Bastuji ${ }^{\mathrm{d}}$ \\ a Instituto de Salud Tropical, Departamento de Microbiología y Parasitología, Universidad de Navarra, 31008, Pamplona, Spain \\ ${ }^{\mathrm{b}}$ Unidad de Sanidad Animal, Centro de Investigación y Tecnología Agroalimentaria (CITA), Gobierno de Aragón, Zaragoza, Spain \\ ${ }^{\mathrm{c}}$ Programa de Investigación en Enfermedades Tropicales, Escuela de Medicina Veterinaria, Universidad Nacional, Costa Rica \\ ${ }^{\mathrm{d}}$ European Union/OIE/FAO Brucellosis Reference Laboratory, French Agency for Food, environmental and Occupational Health Safety (ANSES), F-94706, \\ Maisons-Alfort Cedex, France
}

\section{A R T I C L E I N F O}

\section{Article history:}

Received 18 February 2011

Received in revised form 23 June 2011

Accepted 28 June 2011

\section{Keywords:}

Brucella suis

Brucella canis

Bruce-ladder

PCR

\begin{abstract}
A B S T R A C T
Rapid and specific identification of Brucella suis at the biovar level is necessary because some of the biovars that infect animals are pathogenic for humans. None of the molecular typing methods described so far are able to discriminate $B$. suis biovars in a single test and differentiation of $B$. suis from Brucella canis by molecular approaches can be difficult. This article describes a new multiplex PCR assay, Suis-ladder, for fast and accurate identification of B. suis at the biovar level and the differentiation of B. suis, B. canis and Brucella microti. An advancement of the original Bruce-ladder PCR protocol which allows the correct discrimination of all known Brucella species is also described.
\end{abstract}

(c) 2011 Elsevier B.V. All rights reserved.

\section{Introduction}

Brucella suis, the causative agent of swine brucellosis, is classified in five biovars that infect different animal hosts: biovars 1, 2 and 3 affect domestic pigs, wild boars and hares; biovar 4 infects reindeer and caribou; and biovar 5 infects only rodents. In contrast to biovar 2, biovars 1 and 3 are pathogenic for humans and require high level of biosafety laboratory precautions (Garin-Bastuji and Hars, 2001). The identification and typing of B. suis is currently performed by standard bacteriological and biochemistry methods, but these tests are not straightforward in particular for the identification of biovars 1,2 and 3 (Alton et al., 1988). With the objective of improving the typing of $B$. suis, different PCR-based assays have been

\footnotetext{
* Corresponding author at: Departamento de Microbiología y Parasitología, Universidad de Navarra, c/ Irunlarrea $\mathrm{n}^{\circ} 1,31008$, Pamplona, Spain. Tel.: +34 948 425600; fax: +34 948425649 .

E-mail address: ilgoni@unav.es (I. López-Goñi).
}

proposed. One of these assays is a multiplex conventional PCR (Bruce-ladder) (García-Yoldi et al., 2006; López-Goñi et al., 2008). In general Bruce-ladder performs excellently and has been recommended by the OIE as a rapid and simple one-step molecular test for identification and typing of Brucella species (OIE, 2009). However, its only inconvenience is that some Brucella canis strains and Brucella microti, isolated from common voles and foxes, can be identified erroneously as B. suis (López-Goñi et al., 2008; Scholz et al., 2008). The present report describes a novel multiplex conventional PCR assay (called Suis-ladder) that differentiates between all B. suis biovars and B. canis, and also propose an advancement of the original Bruce-ladder PCR to distinguish between these two species.

\section{Materials and methods}

\subsection{Strains}

To ensure an adequate diversity, a representative collection of $B$. suis and $B$. canis reference strains and field 
Table 1

Oligonucleotides used in the Suis-ladder multiplex PCR assay.

\begin{tabular}{|c|c|c|c|c|}
\hline Primer $^{\mathrm{a}}$ & Sequence $\left(5^{\prime}-3^{\prime}\right)$ & $\begin{array}{l}\text { Amplicon } \\
\text { size (bp) }\end{array}$ & Source of genetic differences & References \\
\hline BMEI1426 & TCG TCG GTG GAC TGG ATG AC & 774 & $\begin{array}{l}\text { Deletion of } 351 \text { bp in } \\
\text { BMEI1426-BMEI1427 in B. canis }\end{array}$ & Zygmunt et al. (2009) \\
\hline BMEI1427 & ATG GTC CGC AAG GTG CTT TT & & & \\
\hline BR1080f & CCC TTG GTT TGT AGC GGT TG & 197 & $\begin{array}{l}\text { Deletion of } 162 \text { bp in BR } 1080 \text { in } \\
\text { B. abortus and B. melitensis }\end{array}$ & Halling et al. (2005) \\
\hline BR1080r & TCA TCG TCC TCC GTC ATC CT & & & \\
\hline BMEI1688 & TCA ACT GCG TGA ACA ATG CT & 278 & $\begin{array}{l}\text { Deletion of } 20,883 \text { bp in } \\
\text { BMEI1674-BMEI } 1703 \text { in } \\
\text { B. suis and B. canis }\end{array}$ & $\begin{array}{l}\text { Rajashekara et al. (2004), } \\
\text { Halling et al. (2005) }\end{array}$ \\
\hline BMEI1687 & GCG GGC TCT ATC TCA AGG TC & & & \\
\hline BMEI0205f & CGT CAA CTC GCT GGC CAA GAG & 299,425 & Derived from VNTR Bruce 11 & Le Flèche et al. (2006) \\
\hline BMEI0205r & GCA GGA GAA CCG CAA CCT AA & 551,614 & & \\
\hline
\end{tabular}

isolates from different geographic origins and different animal species was examined (see supplemental material). When needed, Brucella reference strains were used. All Brucella isolates were typed according to standard procedures (Alton et al., 1988). Growth and harvesting of Brucella cells and bacterial DNA extraction were performed as described elsewhere (García-Yoldi et al., 2006, 2007).

\subsection{Molecular typing}

Isolates were subjected to different PCR-based typing techniques: PCR-RFLP for omp2a, omp2b and omp31 genes (Cloeckaert et al., 1995; Vizcaíno et al., 1997), multiplex AMOS-ery-PCR (Ocampo-Sosa et al., 2005), original multiplex Bruce-ladder (García-Yoldi et al., 2006; López-Goñi et al., 2008), and Brucella MLVA (Le Flèche et al., 2006). A new multiplex PCR (Suis-ladder) able to discriminate among all five biovars of $B$. suis and B. canis was developed. For this, four pairs of oligonucleotide primers were designed and selected based on biovar-specific genetic differences (Table 1). Amplification of DNA was performed in $25 \mu \mathrm{l}$ of a reaction mixture containing $1 \mu \mathrm{l}$ of template DNA, $200 \mu \mathrm{M}$ of each dNTP (Promega Corp.), $2 \mathrm{mM}$ of $\mathrm{MgCl}_{2}, 1 \mathrm{U}$ of Immolase DNA polymerase and its amplification buffer (Bioline Ltd.), and $12.5 \mathrm{pmol}$ of each primer. After an initial denaturation at $95^{\circ} \mathrm{C}$ for $7 \mathrm{~min}$, the PCR profile was set as follows: $35 \mathrm{~s}$ of template denaturation at $95^{\circ} \mathrm{C}, 45 \mathrm{~s}$ of primer annealing at $63^{\circ} \mathrm{C}$, and $60 \mathrm{~s}$ of primer extension at $72^{\circ} \mathrm{C}$, for a total of 30 cycles, with a final extension at $72{ }^{\circ} \mathrm{C}$ for $6 \mathrm{~min}$. PCR products were analyzed by standard $1.5-2.0 \%$ agarose electrophoresis.

\section{Results and discussion}

A representative example of the multiplex Suis-ladder PCR result is presented in Fig. 1. PCR using B. suis DNAs from the five reference biovars gave different band profiles: biovar 1 amplified three fragments of 774, 425 and $197 \mathrm{bp}$; biovar 2 amplified three fragments of 774, 551 and 278 bp; biovar 3 amplified three fragments of 774, 299 and $197 \mathrm{bp}$; biovar 4 amplified three fragments of 774, 614 and $197 \mathrm{bp}$; and biovar 5 amplified four fragments of 774 bp, 614, 278 and 197 bp. Then, the Suis-ladder PCR was applied to a total of 99 B. suis field isolates (see supplemental material). All isolates from $B$. suis biovars 1, 2 and 4 displayed the same PCR profiles to the corresponding type strains (Fig. 1), consistent with the biovar assigned by biochemical and molecular characterization. The only exceptions were few $B$. suis field isolates identified by standard microbiological tests as biovar 3 (see supplemental material). Two of these isolates (refs. 03-3081-02 and 01-1825-04) were typed as biovar 3 also by MLVA but were classified as biovar 1 by PCR-RFLP for omp genes, AMOS-ery-PCR and the new Suis-ladder. On the other hand, three isolates (refs. 04-3025-03, 04-1361-S4, 04-1361-S5) were typed as biovar 3 only by standard microbiological procedures but as biovar 1 by all other molecular techniques. The existence of $B$. suis field strains typed as biovar 3 with the classical biochemical scheme that fit with the genetic profiles of biovar 1 has been described by others (Ferrao-Beck et al., 2006; Le Flèche et al., 2006; Whatmore et al., 2006; Fretin et al., 2008; Huber et al., 2009) and confirms that the taxonomical situation of $B$. suis biovar 3 can be questioned (Fretin et al., 2008).

When the Suis-ladder PCR was applied to the $B$. canis reference strain a specific PCR profile clearly different from B. suis was obtained: only two fragments of 614 and $197 \mathrm{bp}$ were amplified (Fig. 1). Interestingly, the 774 bp fragment common to all $B$. suis biovars was not obtained with $B$. canis

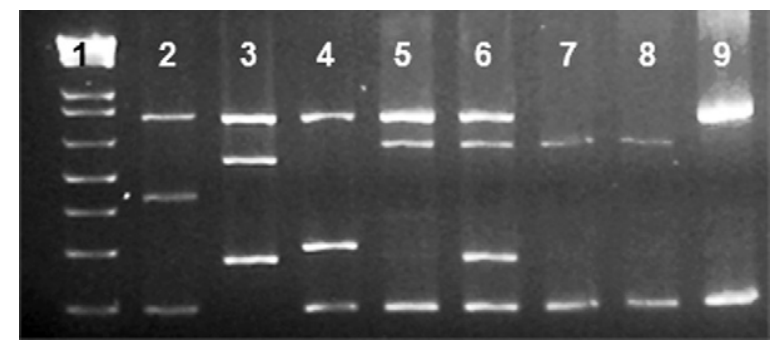

Fig. 1. Suis-ladder multiplex PCR: differentiation of all $B$. suis biovars, $B$. canis and B. microti. Lane 1 , molecular marker $1 \mathrm{~kb}$ plus DNA ladder (Invitrogen Ltd.); lane 2, B. suis biovar 1 strain 1330; lane 3, B. suis biovar 2 strain Thomsen; lane 4, B. suis biovar 3 strain 686; lane $5, B$. suis biovar 4 strain 40; lane $6, B$. suis biovar 5 strain ELT80; lane 7, B. canis, with a $B$. canis profile in the original Bruce-ladder; lane $8, B$. canis, with a $B$. suis profile in the original Bruce-ladder; lane 9, B. microti. 


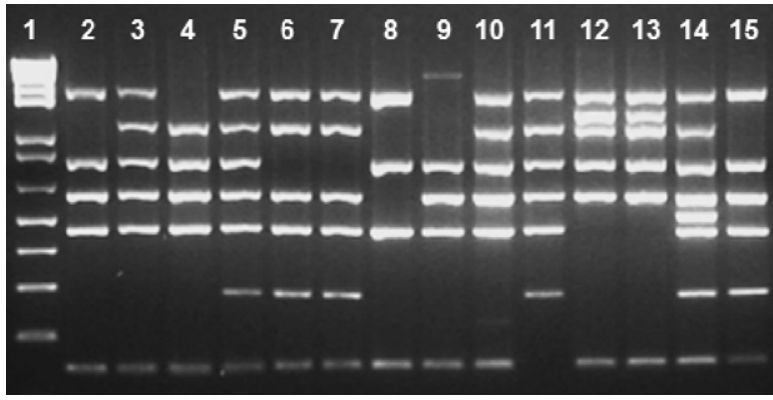

Fig. 2. Bruce-ladder v2.0 multiplex PCR: differentiation of all known Brucella species and vaccine strains. Lane 1, molecular marker molecular marker $1 \mathrm{~kb}$ plus DNA ladder (Invitrogen Ltd.); lane 2, B. abortus; lane 3, $B$. melitensis; lane $4, B$. ovis; lane $5, B$. suis; lane $6, B$. canis isolate with a $B$. canis profile in the original Bruce-ladder; lane $7, B$. canis isolates with a $B$. suis profile in the original Bruce-ladder; lane 8, B. abortus S19; lane 9, $B$. abortus RB51; lane 10, B. melitensis Rev.1; lane 11, B. neotomae; lane 12, B. pinipedialis; lane $13, B$. ceti; lane $14, B$. microti; lane $15, B$. inopinata.

DNA. The Suis-ladder PCR was then applied to a total of 17 $B$. canis field isolates (see supplemental material), included $6 B$. canis strains that previously were misidentified as $B$. suis by the original Bruce-ladder PCR. All B. canis field isolates gave the same PCR profile to the corresponding $B$. canis type strain, confirming the identity of all isolates as $B$. canis. The Suis-ladder PCR was also able to differentiate $B$. microti strain by the presence of two bands of 774 and 197 bp (Fig. 1).

In the original Bruce-ladder protocol PCR seven amplicons (1682, 1071, 794, 587, 450, 272 and $152 \mathrm{bp}$ ) were expected from $B$. suis DNA, and $B$. canis was distinguished by the absence of the $794 \mathrm{bp}$ fragment (García-Yoldi et al., 2006). However, as mentioned before, some $B$. canis strains were identified erroneously as $B$. suis. To overcome this problem, here we also propose the advancement of this PCR protocol by substituting the primers BMEI1436f/BMEI1435r in the original primer mix by the new primers BMEI1426/1427 (Table 1), which amplified a 774 bp fragment from the $w b k F-w b k D$ region (Zygmunt et al., 2009). In addition, the primer pair identifying $B$. microti described before was also included (Mayer-Scholl et al., 2010). An example of the modified Bruce-ladder PCR (called Bruce-ladder v2.0) is presented in Fig. 2. The new primer pair did not interfere with the other primers present in the cocktail mix. All B. canis field strains tested were distinguished to $B$. suis by the absence of the $774 \mathrm{bp}$ fragment, confirming that the deletion of this genetic region is specific for $B$. canis and can be used in the Bruce-ladder v2.0 to discriminate between $B$. suis and $B$. canis.

In conclusion, for the differentiation of all $B$. suis biovars, $B$. canis and B. microti we propose a two steps PCR assays. First, by the advancement Bruce-ladder v2.0 PCR it is possible to identify correctly all known Brucella species and vaccine strains. Second, by the new Suis-ladder PCR it is possible differentiate the $B$. suis biovars. These rapid and robust multiplex PCR systems are important tools for routine laboratories for effective diagnosis of animal brucellosis in domestic and wild animals, and can contribute to the control and eradication of the disease.

\section{Acknowledgements}

This work was partially supported by Ministerio de Educación y Ciencia, Spain (AGL2008-04514, PET20080027 and FAU2008-00015). We want to express our gratitude to Pilar Ma Muñoz, Zeljko Cvetnic, David Fretin, Maria Silvia Gennero, Falk Melzer, R. Miserez, Lorraine Perrett, and Isabel Travassos for providing some of the Brucella isolates.

\section{Appendix A. Supplementary data}

Supplementary data associated with this article can be found, in the online version, at doi:10.1016/j.vetmic.2011.06.035.

\section{References}

Alton, G.G., Jones, L.M., Angus, R.D., Verger, J.M., 1988. Techniques for the Brucellosis Laboratory. Institut National de la Recherche Agronomique, Paris.

Cloeckaert, A., Verger, J.M., Grayon, M., Grépinet, O., 1995. Restriction site polymorphism of the genes encoding the major $25 \mathrm{kDa}$ and 36 outermembrane proteins of Brucella. Microbiology 141, 2111-2121.

Ferrao-Beck, L., Cardoso, R., Muñoz, P.M., de Miguel, M.J., Albert, D., Ferreira, A.C., Marín, C.M., Thiebaud, M., Jacques, I., Grayon, M., Zygmunt, M.S., Garín-Bastuji, B., Blasco, J.M., Sa, M.I., 2006. Development of a multiplex PCR assay for polymorphism analysis of Brucella suis biovars causing brucellosis in swine. Vet. Microbiol. 115, 269-277.

Fretin, D., Whatmore, A.M., Al Dahouk, S., Neubauer, H., Garin-Bastuji, B., Albert, D., Van Hessche, M., Ménart, M., Godfroid, J., Walravens, K., Wattiau, P., 2008. Brucella suis identification and biovar typing by real-time PCR. Vet. Microbiol. 131, 376-385.

García-Yoldi, D., Marín, C.M., de Miguel, M.J., Muñoz, P.M., Vizmanos, J.L., López-Goñi, I., 2006. Multiplex PCR assay for the identification and differentiation of all Brucella species and the vaccine strains Brucella abortus S19 and RB51 and Brucella melitensis Rev1. Clin. Chem. 52, 779-781.

García-Yoldi, D., Le Fleche, P., De Miguel, M.J., Muñoz, P.M., Blasco, J.M. Cvetnic, Z., Marín, C.M., Vergnaud, G., López-Goñi, I., 2007. Comparison of multiple-locus variable-number tandem-repeat analysis with other PCR-based methods for typing Brucella suis isolates. J. Clin. Microbiol. 45, 4070-4072.

Garin-Bastuji, B., Hars, J., 2001. Situation epidemiologique de la brucellose a Brucella suis biovar 2 en France. Bull. Epidemiol. 2.

Halling, S.M., Peterson-Burch, B.D., Bricker, B.J., Zuerner, R.L., Qing, Z., Li, L.L., Kapur, V., Alt, D.P., Olsen, S.S., 2005. Completion of the genome sequence of Brucella abortus and comparison to the highly similar genomes of Brucella melitensis and Brucella suis. J. Bacteriol. 187, 2715-2726.

Huber, B., Scholz, H.C., Lucero, N., Busse, H.J., 2009. Development of a PCR assay for typing and subtyping of Brucella species. Int. J. Med. Microbiol. 299, 563-573.

Le Flèche, P., Jacques, I., Grayon, M., Al Dahouk, S., Bouchon, P., Denoeud, F., Nockler, K., Neubauer, H., Guilloteau, L.A., Vergnaud, G., 2006. Evaluation and selection of tandem repeat loci for a Brucella MLVA typing assay. BMC Microbiol. 6, 9.

López-Goñi, I., García-Yoldi, D., Marín, C.M., de Miguel, M.J., Muñoz, P.M., Blasco, J.M., Jacques, I., Grayon, M., Cloeckaert, A., Ferreira, A.C., Cardoso, R., Corrêa de Sá, M.I., Walravens, K., Albert, D., Garin-Bastuji, B., 2008. Evaluation of a multiplex PCR assay (Bruce-ladder) for molecular typing of all Brucella species, including the vaccine strains. J. Clin. Microbiol. 46, 3484-3487.

Mayer-Scholl, A., Draeger, A., Göllner, C., Scholz, H.C., Nöckler, K.J., 2010 Advancement of a multiplex PCR for the differentiation of all currently described Brucella species. Microbiol. Methods 80 (1), 112-114.

OIE, 2009. Manual of diagnostic test and vaccines for terrestrial animals In: Bovine Brucellosis, Office International des epizootics, Paris, Chapter 2.4.3.

Ocampo-Sosa, A.A., Agüero-Balbin, J., García-Lobo, J.M., 2005. Development of a new PCR assay to identify Brucella abortus biovars 5, 6 and 9 and the new subgroup 3b of biovar 3. Vet. Microbiol. 110, 41-51. 
Rajashekara, G., Glasner, J.D., Glover, D.A., Splitter, G.A., 2004. Comparative whole-genome hybridization reveals genomic islands in Brucella species. J. Bacteriol. 186, 5040-5051.

Scholz, H.C., Hubalek, Z., Sedlacek, I., Vergnaud, G., Tomaso, H., Al Dahouk, S., Melzer, F., Kämpfer, P., Neubauer, H., Clockaert, A., Maquart, M., Zygmunt, M.S., Whatmore, A.M., Falsen, E., Bahn, P., Göllner, C., Pfeffer, M., Huber, B., Busse, H.J., Nöckler, K., 2008. Brucella microti sp. nov., isolated from the common vole Microtus arvalis. Int. J. Syst. Evol. Microbiol. 58, 375-382.

Vizcaíno, N., Verger, J.M., Grayon, M., Zygmunt, M.S., Cloeckaert, A., 1997. DNA polymorphism at the omp-31 locus of Brucella spp.: evidence for a large deletion in Brucella abortus, and other species-specific markers. Microbiology 143, 2913-2921.

Whatmore, A.M., Shankster, S.J., Perrett, L.L., Murphy, T.J., Brew, S.D. Thirlwall, R.E., Cutler, S.J., MacMillan, A.P., 2006. Identification and characterisation of variable-number tandem-repeat markers for typing of Brucella spp. J. Clin. Microbiol. 44, 1982-1993.

Zygmunt, M.S., Blasco, J.M., Letesson, J.J., Cloeckaert, A., Moriyón, I., 2009. DNA polymorphism analysis of Brucella lipopolysaccharide genes reveals marked differences in O-polysaccharide biosynthetic genes between smooth and rough Brucella species and novel species-specific markers. BMC Microbiol. 13 (9), 92. 